\title{
Pengaruh Pemberian Pupuk NPK Phonska dan Pupuk Biourine Sapi Terhadap Pertumbuhan Bibit Pisang Rutai (Musa sp).
}

\section{The Influence of Fertilizer NPK Phonska and Biourine Cow Fertilizer on the Growth of Banana Seeds of Rutai (Musa sp).}

\author{
Kardiansyah $^{1}$, Purwati ${ }^{2}$, Iin Arsensi ${ }^{2}$ \\ ${ }^{1}$ Alumni Program Studi Agroteknologi, Fakultas Pertanian, Universitas Widya Gama Mahakam \\ ${ }^{2}$ Tenaga Pendidik Program Studi Agroteknologi, Fakultas Pertanian, Universitas Widya Gama Mahakam \\ Jl. KH. Wahid Hasyim, Sempaja, Samarinda, Kalimantan Timur, Indonesia \\ email : kardiansyah@gmail.com, purwati@uwgm.ac.id, iinarsensi@uwgm.ac.id
}

Diterima : 17 Mei 2017 Disetujui : 2 Juni 2017

\begin{abstract}
The Influence of Fertilizer NPK Phonska and Biourine Cow Fertilizer on the Growth of Banana Seeds of Rutai (Moses sp). The purpose of this study was to determine the effect of NPK Phonska and Biourine Cow Fertilizer on the Growth of Banana Seeds of Rutai. This study was conducted for 3 months, ie from September to December 2014. Research Campus Widya Gama Mahakam Samarinda. This research was arranged in Randomized Block Design $(R A K)$ with $3 \times 3$ Experiment with 3 replications. The first factor is the provision of NPK Phonska $(P)$ Fertilizer consisting of 3 levels, namely: po (control), p1 (50 grams of Phonska NPK fertilizer / plant), p2 (Provision of 100 grams of Phonska NPK fertilizer / plant). While the second factor is the provision of Biourine Cow Fertilizer (U) consisting of 3 levels, namely: u0 (Control), ul (Giving $10 \mathrm{ml}$ of Biourine Fertilizer / Plant), and u2 (Giving $15 \mathrm{ml}$ of Biourine Fertilizer / Cow). The result showed that fertilizer NPK Phonska with dose of $100 \mathrm{~g} /$ plant / polybag (p2) can increase the growth of rutai banana seedlings where the highest growth parameters were 16 and 20 weeks after planting $15.89 \mathrm{~cm}$ and $21.25 \mathrm{~cm}$, Then the parameter of increase of diameter is at 16 weeks after planting is $5,50 \mathrm{~cm}$, and for parameter increase of leaf amount is at 16,20 and 24 weeks after planting that is 1,89 strands, 2,11 strands and 2,22 strands. Giving of Biourine Fertilizer Cow with dosage of $15 \mathrm{ml} /$ liter of water / polybag (u2) can increase the growth of rutai banana seedlings where the highest highest plant growth parameters are at 16, and 20 weeks after planting ie $16.67 \mathrm{~cm}$ and $22.28 \mathrm{~cm}$, then The parameter of diameter increase is 16 weeks after planting is $63,50 \mathrm{~cm}$, and for parameter increase of leaf number is at 16, and 24 weeks after planting that is 1,89 strands and 2,22 strands. The interaction treatment between NPK Phonska and Biourine Sapi fertilizer between 100 grams of NPK Phonska and Biourine Sapi $15 \mathrm{ml} /$ liter of water / plant (p2u2) can increase the growth of rutai banana plants, where the parameters of plant height increase is 16, 20 weeks after planting 19,67 cm and 30,20 cm, then at parameter of diameter increase is at 16 weeks after planting that is $4,59 \mathrm{~cm}$, and on parameter of increase of leaf number is at 16, 20 and 24 weeks after planting that is 5,14 strands, 2, 67 strands and 3,00 strands.
\end{abstract}

Keywords: NPK Phonska, Biourine Cow Fertilizer and Banana Rutai

\section{PENDAHULUAN}

Pisang adalah tanaman herba yang berasal dari Asia Tenggara termasuk Indonesia.Tanaman buah ini kemudian menyebar luas kekawasan Afrika (Madagaskar), Amerika Selatan, Amerika Tengah. Penyebaran tanaman ini selanjutnya hamper merata keseluruh dunia, yakni meliputi daerah tropic dan subtropik, dimulai dari Asia Tenggara ke Timur melalui Lautan Teduh sampai ke Hawai. Selain itu tanaman pisang menyebar kebarat melalui Samudra Atlantik, kepulauan Kanari, sampai Benua Amerika(Satuhu, 2008).

Pisang sebagai tanaman hortikultura, pengembangannya hingga saat ini masih diusahakan oleh masyarakat hanya sebagai pengisi tanah pekarangan rumah ataupun pada pematang-pematang sawah dan tegalan. Usaha ini masih merupakan usahatani yang subsisten yang tidak memperhatikan jarak tanam, pemupukan, pengairan, pemberantasan hama dan penyakit, dan pemeliharaan yang lain seperti penyiangan.

Pola usahatani perkarangan tanaman pisang ini dapat kita jumpai pada hamper setiap tanah pekarangan rumah, pematang-pematang tegalan atau sawah, dan sepanjang tepi sungai.Sistem pembudidayaan pisang secara tradisional ini pada kenyataannya tidak dapat berperoduksi secara maksimal.

Kabupaten Kutai Kartanegara memiliki ratusan jenis buah-buahan yang saat ini boleh dikatakan langka. Buah-buahan yang sebagian besar dulunya merupakan buah yang pohonnya tumbuh di hutan sekitar desa-desa dan hutan rimba secara liar itu, sebagian ada juga yang ditanam di kebun-kebun warga.

Salah satu jenis buah khas kutai yang kini juga mulai langka adalah pisang Rutai. Buah pisang Rutai yang berukuran kecil itu sangat disukai banyak orang, selain aromanya juga 
rasanya yang sangat manis dengan kandungan vitamin yang tinggi. Untuk jenis pisang rutai ini tidak banyak warga yang menanam, untuk itu, demi menjaga kemungkinan buah pisang rutai yang mulai langka (punah), karena tidak banyak petani yang membudidayakan pisang rutai, di samping bibitnya yang sulit di temukan (tumbuh di hutan). Umur tanaman hingga produksinya pun cukup lama sekitar 1,5tahun baru belajar berbuah(Anonim, 2010).

\section{BAHAN DAN METODE}

Penelitian dilaksanakan selama 3 bulan, yaitu dari bulan September sampai bulan Desember 2014. Tempat Penelitian Kampus Widya Gama Mahakam Samarinda. Bahan yang digunakan biourine sapi yang difermentasikan, pupuk NPK Phonska, tanah, air, polybag ukuran 35 x $40 \mathrm{~cm}$, bibit pisang Rutai umur 3 bulan. Penelitian disusun dalam Rancangan Acak Kelompok (RAK) dengan Percobaan 3 x 3 dengan 3 ulangan. Setiap perlakuan terdiri dari 9 tanaman pengamatan. Faktor pertama adalah pemberian Pupuk NPK Phonska (P) yang terdiri dari 3 taraf yaitu : $\mathrm{p}_{\mathrm{o}}$ (kontrol), $\mathrm{p}_{1}$ (50 gram pemberian Pupuk NPK Phonska/tanaman ), $\mathrm{p}_{2}$ (Pemberian 100 gram Pupuk NPK Phonska/tanaman). Sedangkan faktor kedua yaitu pemberian Pupuk Biourine Sapi (U) yang terdiri

\section{HASIL DAN PEMBAHASAN}

\section{Pengaruh Pupuk NPK Phonska}

\section{Tinggi Tanaman}

Berdasarkan hasil analisis sidik ragam pemberian pupuk NPK Phonska berpengaruh nyata terhadap tinggi tanaman pisang rutai umur
Saat ini belum banyak informasi tentang budidaya tanaman pisang Rutai dengan pemberian pupuk NPK Phonska dan Biourine Sapi.

Berdasarkan uraian diatas maka penelitian ini dilakukan untuk mengetahui pengaruh pemberian pupuk NPK Phonska dan Biourine Sapi terhadap pertumbuhan bibit tanaman pisang rutai.

dari 3 taraf, yaitu : $\mathrm{u}_{0}$ (Kontrol), $\mathrm{u}_{1}$ (Pemberian $10 \mathrm{ml}$ Pupuk Biourine Sapi/tanaman), dan $\mathrm{u}_{2}$ (Pemberian $15 \mathrm{ml}$ Pupuk Biourine Sapi/tanaman). Pelaksanaan penelitian meliputi : pembuatan biourine sapi, penyiapan lahan, persiapan media, pemilihan bibit pisang, penanaman bibit pisang di polybag, pemeliharaan (penyiraman, dan penyiangan), pemupukan dengan NPK Phonska,, perlakuan biourine sapi. Pengambilan data meliputi : pertambahan tinggi tanaman, pertambahan jumlah daun, pertambahan diameter batang. Data di analisis dengan menggunakan sidik ragam, apabila ada pengaruh maka dilakukan Uji lanjutan dengan menggunakan Uji Beda Nyata Terkecil (BNT) pada taraf 5\% untuk membandingkan dua rata-rata perlakuan.

Tabel 1. Pengaruh Pupuk NPK Phonska (P) Terhadap Pertambahan Rata-Rata Tinggi Tanaman (cm)

\begin{tabular}{cccc}
\hline Perlakuan Pupuk NPK & \multicolumn{3}{c}{ Tinggi Tanaman } \\
\cline { 2 - 4 } Phonska & $16 \mathrm{MST}$ & $20 \mathrm{MST}$ & $24 \mathrm{MST}$ \\
\hline $\mathrm{p}_{0}$ & $9,22 \mathrm{c}$ & $11,35 \mathrm{c}$ & $16,55 \mathrm{c}$ \\
$\mathrm{p}_{1}$ & $13,11 \mathrm{~b}$ & $17,34 \mathrm{~b}$ & $26,33 \mathrm{a}$ \\
$\mathrm{p}_{2}$ & $15,89 \mathrm{a}$ & $21,25 \mathrm{a}$ & $24,78 \mathrm{~b}$ \\
\hline
\end{tabular}

Keterangan : Angka yang diikuti huruf yang sama menyatakan tidak berbeda nyata pada BNT 5\% (BNT p = 0,22) pertambahan tinggi tanaman umur $16 \mathrm{MST}$, pada $(\mathrm{BNT} \mathrm{p}=0,33)$ pertambahan tinggi tanaman umur $20 \mathrm{MST}$, dan pada BNT 5\% (BNT p = 0,22) pertambahan tinggi tanaman umur $24 \mathrm{MST}$.

Umur 20 mst berpengaruh nyata dengan nilai yang tertinggi adalah perlakuan $\mathrm{p}_{2}$ yaitu $15,89 \mathrm{~cm}$, dan yang terendah adalah perlakuan $\mathrm{p}_{0}$ yaitu 9,22 cm, serta umur $24 \mathrm{mst}$ berpengaruh sangat nyata dengan nilai yang tertinggi adalah $\mathrm{p}_{1}$ yaitu $26,33 \mathrm{~cm}$ dan nilai yang terendah adalah $\mathrm{p}_{0}$ yaitu $16,55 \mathrm{~cm}$.
Berpengaruhnya NPK Phonska terhadap parameter tinggi tanaman, hal ini diduga serapan $\mathrm{N}$ oleh tanaman cukup efektif, Winarso (2005), menyatakan sebagian besar $\mathrm{N}$ dalam tanah dalam bentuk senyawa organik tanah dan tidak tersedia bagi tanaman, fiksasi N-organik di sekitar $95 \%$ dari total $\mathrm{N}$ yang ada dalam tanah. 


\section{Diameter Batang}

Berdasarkan hasil analisis sidik ragam pemberian pupuk NPK Phonska berpengaruh sangat nyata terhadap pertambahan diameter batang tanaman pisang rutai umur $16 \mathrm{mst}$

dengan nilai yang tertinggi adalah perlakuan $\mathrm{p}_{2}$ yaitu $5,50 \mathrm{~cm}$ dan nilai yang terendah perlakuan $\mathrm{p}_{0}$ yaitu $2,20 \mathrm{~cm}$.

Tabel 2. Pengaruh Pupuk NPK Phonska (P) Terhadap Pertambahan Rata-Rata Diameter Batang (cm)

\begin{tabular}{cccc}
\hline Perlakuan Pupuk NPK & \multicolumn{3}{c}{ Diameter Batang } \\
\cline { 2 - 4 } Phonska & $16 \mathrm{MST}$ & $20 \mathrm{MST}$ & $24 \mathrm{MST}$ \\
\hline $\mathrm{p}_{0}$ & $2,20 \mathrm{c}$ & $2,30 \mathrm{c}$ & $2,44 \mathrm{c}$ \\
$\mathrm{p}_{1}$ & $3,02 \mathrm{~b}$ & $4,12 \mathrm{a}$ & $4,99 \mathrm{a}$ \\
$\mathrm{p}_{2}$ & $4,02 \mathrm{a}$ & $3,26 \mathrm{~b}$ & $4,01 \mathrm{~b}$ \\
\hline
\end{tabular}

Keterangan : Angka yang diikuti huruf yang sama menyatakan tidak berbeda nyata pada BNT 5\% (BNT $\mathrm{p}=0,03$ ) pertambahan diameter batang umur $16 \mathrm{MST}$, pada $(\mathrm{BNT} \mathrm{p}=0,04)$ pertambahan diameter batang umur 20 MST, dan pada BNT 5\% (BNT p = 0,05) pertambahan diameter batang umur 24 MST.

Umur 20 MST berpengaruh sangat nyata dengan nilai tertinggi adalah perlakuan $\mathrm{p}_{1}$ yaitu $4,12 \mathrm{~cm}$ dan nilai yang terendah adalah perlakuan $\mathrm{p}_{0}$ yaitu $2,30 \mathrm{~cm}$. Kemudian umur 24 MST berpengaruh sangat nyata dengan nilai tertinggi adalah perlakuan $\mathrm{p}_{1}$ yaitu $4,99 \mathrm{~cm}$ dan nilai yang terendah adalah perlakuan $\mathrm{p}_{0}$ yaitu $2,44 \mathrm{~cm}$.

\section{Jumlah Daun}

Berdasarkan hasil sidik ragam pemberian pupuk NPK Phonska berpengaruh nyata terhadap pertambahan jumlah daun tanaman pisang rutai
Pengaruh NPK Phonska terhadap parameter diameter tanaman, tidak terlepas dari pemberian NPK Phonska yang dilakukan, seperti dijelaskan oleh Winarso (2005), bahwa pemupukan $\mathrm{N}$ pada tanah-tanah yang kekurangan $\mathrm{N}$ dapat meningkatkan kadar $\mathrm{N}$ dan hasil tanaman.

Tabel 3. Pengaruh Pupuk NPK Phonska (P) Terhadap Pertambahan Rata-Rata Jumlah Daun (helai)

\begin{tabular}{cccc}
\hline Perlakuan Pupuk NPK & \multicolumn{3}{c}{ Jumlah Daun } \\
\cline { 2 - 4 } Phonska & $16 \mathrm{MST}$ & $20 \mathrm{MST}$ & $24 \mathrm{MST}$ \\
\hline $\mathrm{p}_{0}$ & $1,33 \mathrm{c}$ & $1,33 \mathrm{~b}$ & $1,67 \mathrm{~b}$ \\
$\mathrm{p}_{1}$ & $1,44 \mathrm{~b}$ & $1,22 \mathrm{c}$ & $1,67 \mathrm{~b}$ \\
$\mathrm{p}_{2}$ & $1,89 \mathrm{a}$ & $2,11 \mathrm{a}$ & $2,22 \mathrm{a}$ \\
\hline
\end{tabular}

Keterangan : Angka yang diikuti huruf yang sama menyatakan tidak berbeda nyata pada BNT 5\% (BNT p = 0,02) pertambahan jumlah daun umur $16 \mathrm{MST}$, pada $(\mathrm{BNT} \mathrm{p}=0,01)$ pertambahan jumlah daun umur 20 MST, dan pada BNT 5\% (BNT p = 0,02) pertambahan jumlah daun umur 24 MST.

Untuk umur 20 MST berpengaruh sangat nyata dengan jumlah tertinggi adalah perlakuan $\mathrm{p}_{2}$ yaitu 2,11 helai dan jumlah yang terendah adalah perlakuan $\mathrm{p}_{1}$ yaitu 1,22 helai daun dan umur 24 MST berpengaruh nyata jumlah tertinggi adalah perlakuan $\mathrm{p}_{2}$ yaitu 2,22 helai daun dan nilai yang terenda adalah $\mathrm{p}_{1}$ dan $\mathrm{p}_{0}$ yaitu 1,67 helai daun. Tanaman mengandung cukup $\mathrm{N}$ akan menunjukkan warna daun hijau tua yang artinya kadar klorofil dalam daun tinggi, sebaliknya apabila tanaman kekurangan atau defisiensi $\mathrm{N}$ maka daun akan menguning (klorosis), karena kekurangan klorofil. Berpengaruhnya pemberian pupuk NPK Phonska terhadap parameter jumlah daun menggambarkan bahwa pemupukan dengan cara penaburan lebih efisien karena lebih banyak unsur tersedia yang diserap tanaman (Winarso, 2005). 


\section{Pengaruh Pupuk Biourine Sapi}

\section{Tinggi Tanaman}

Hasil analisis sidik ragam pemberian pupuk Biourine Sapi berpengaruh nyata terhadap pertambahan tinggi tanaman pisang rutai 16 MST dengan nilai tertinggi adalah perlakuan $\mathrm{u}_{2}$ yaitu $20,71 \mathrm{~cm}$ dan terendah adalah perlakuan $\mathrm{u}_{0}$ yaitu $13,45 \mathrm{~cm}$. Pada umur 20 MST berpengaruh nyata nilai tertinggi adalah $\mathrm{u}_{2}$ yaitu $16,67 \mathrm{~cm}$ dan nilai yang terendah adalah perlakuan $\mathrm{u}_{0}$ yaitu $10,44 \mathrm{~cm}$, kemudian pada umur 24 MST berpengaruh nyata dengan nilai tertinggi adalah perlakuan $\mathrm{u}_{1}$ yaitu $26,33 \mathrm{~cm}$ dan nilai terendah adalah perlakuan $\mathrm{u}_{0}$ yaitu $18,78 \mathrm{~cm}$.

Tabel 4. Pengaruh Pupuk Biourine Sapi (U) Terhadap Pertambahan Rata-Rata Tinggi Tanaman (cm)

\begin{tabular}{cccc}
\hline Perlakuan Pupuk & \multicolumn{3}{c}{ Tinggi Tanaman } \\
\cline { 2 - 4 } Biourine Sapi & $16 \mathrm{MST}$ & $20 \mathrm{MST}$ & $24 \mathrm{MST}$ \\
\hline $\mathrm{u}_{0}$ & $10,44 \mathrm{c}$ & $13,45 \mathrm{c}$ & $18,78 \mathrm{c}$ \\
$\mathrm{u}_{1}$ & $11,11 \mathrm{~b}$ & $15,77 \mathrm{~b}$ & $26,33 \mathrm{a}$ \\
$\mathrm{u}_{2}$ & $16,67 \mathrm{a}$ & $22,28 \mathrm{a}$ & $22,55 \mathrm{~b}$ \\
\hline
\end{tabular}

Keterangan : Angka yang diikuti huruf yang sama menyatakan tidak berbeda nyata pada BNT 5\% (BNT u $=0,22$ ) pertambahan tinggi tanaman umur $16 \mathrm{MST}$, pada $(\mathrm{BNT} \mathrm{u}=0,33$ ) pertambahan tinggi tanaman umur $20 \mathrm{MST}$, dan pada BNT 5\% (BNT u = 0,22) pertambahan tinggi tanaman umur 24 MST.

Dugaan berpengaruhnya pupuk Biourine Sapi terhadap pertumbuhan tinggi tanaman tidak terlepas dari sifat pupuk Biourine Sapi sendiri, karena memiliki kandungan hara yang lengkap.Seperti dikutip dari pendapat Bilad, (2011) bahwa Urine sapi sangat baik digunakan sebagai pupuk organik cair karena memiliki kandungan hara yang lengkap. Meskipun bergantung pada lokasi dan sumbernya (makanan), kandungan $\mathrm{N}$ sekitar $1,5-2 \%$ serta $\mathrm{P}$ dan S nya 0,15-2\%, unsur Airnya 75-90\%

\section{Diameter Batang}

Berdasarkan hasil analisis sidik ragam pemberian pupuk Biourine Sapi berpengaruh nyata terhadap diameter batang tanaman pisang rutai umur 16 MST dengan nilai tertinggi adalah berada sebagai urea sedangkan sisanya dalam bentuk amonium atau kreatinin. Sedangkan $\mathrm{P}$ dan S nya hampir $90-100 \%$ berbentuk inorganik terlarut serta secara langsung dapat di konsumsi oleh tumbuhan.Adanya aktivitas urease menyebabkan terjadinya dekomposisi secara cepat menjadi air dan Amonium.Reaksi ini memicu meningkatnya $\mathrm{pH}$ sampai 9 dan meningkatkan penguapan Amonium serta menurunkan populasi bakteri.

perlakuan $\mathrm{u}_{0}$ yaitu $4,40 \mathrm{~cm}$ dan nilai terendah adalah perlakuan $\mathrm{u}_{1}$ yaitu $3,02 \mathrm{~cm}$. Pada umur 20 MST tidak berpengaruh nyata, dan pada umur 24 MST tidak berpengaruh nyata.

Tabel 5. Pengaruh Pupuk Biourine Sapi (U) Terhadap Pertambahan Rata-Rata Diameter Batang (cm)

\begin{tabular}{cccc}
\hline Perlakuan Pupuk & \multicolumn{3}{c}{ Diameter Batang } \\
\cline { 2 - 4 } Biourine Sapi & $16 \mathrm{MST}$ & $20 \mathrm{MST}$ & $24 \mathrm{MST}$ \\
\hline $\mathrm{u}_{0}$ & $2,55 \mathrm{c}$ & 2,68 & 3,08 \\
$\mathrm{u}_{1}$ & $3,18 \mathrm{~b}$ & 3,66 & 3,85 \\
$\mathrm{u}_{2}$ & $3,50 \mathrm{a}$ & 3,35 & 4,50 \\
\hline
\end{tabular}

Keterangan : Angka yang diikuti huruf yang sama menyatakan tidak berbeda nyata pada BNT 5\% (BNT u = 0,03) pertambahan diameter batang umur 16 MST

Berpengaruhnya pupuk Biourine Sapi terhadap diameter batang tanaman pisang rutai umur $16 \mathrm{MST}$, namun tidak berpengaruh pada diameter batang umur 20 dan 24 MST, ini diduga karena nitrogen dalam tanaman bisa bersifat mobil (bergerak), artinya kekurangan nitrogen dalam jaringan tua akan dimobilisasi ke jaringan-jaringan muda (titik-titik tumbuh) sehingga pada jaringan tua klorosis sedangkan pada jaringan muda atau titik tumbuh masih hijau (Winarso, 2005). 


\section{Jumlah Daun}

Berdasarkan hasil analisis sidik ragam pemberian pupuk Biourine sapi berpengaruh nyata terhadap pertambahan jumlah daun pada umur 16 MST dengan jumlah tertinggi adalah perlakuan $\mathrm{u}_{2}$ yaitu 1,89 helai daun dan jumlah terendah adalah perlakuan $\mathrm{u}_{0}$ yaitu 1,33 helai daun. Pada umur 20 MST berpengaruh nyata dengan jumlah tertinggi adalah perlakuan $\mathrm{u}_{1} 1,78$ helai daun dan jumlah terendah adalah perlakuan $\mathrm{u}_{0}$ yaitu 1,22 helai daun dan pada umur 24 MST berpengaruh nyata dengan jumlah yang tertinggi adalah perlakuan $\mathrm{u}_{2}$ yaitu 2,22 helai daun dan jumlah yang terendah adalah perlakuan $\mathrm{u}_{1}$ yaitu 1,56 helai daun.

Tabel 6. Pengaruh Pupuk Biourine Sapi (U) Terhadap Pertambahan Rata-Rata Jumlah Daun (helai)

\begin{tabular}{cccc}
\hline Perlakuan Pupuk & \multicolumn{3}{c}{ Jumlah Daun } \\
\cline { 2 - 4 } Biourine Sapi & $16 \mathrm{MST}$ & $20 \mathrm{MST}$ & $24 \mathrm{MST}$ \\
\hline $\mathrm{u}_{0}$ & $1,33 \mathrm{c}$ & $1,22 \mathrm{c}$ & $1,78 \mathrm{~b}$ \\
$\mathrm{u}_{1}$ & $1,45 \mathrm{~b}$ & $1,78 \mathrm{a}$ & $1,56 \mathrm{c}$ \\
$\mathrm{u}_{2}$ & $1,89 \mathrm{a}$ & $1,67 \mathrm{~b}$ & $2,22 \mathrm{a}$ \\
\hline
\end{tabular}

Keterangan : Angka yang diikuti huruf yang sama menyatakan tidak berbeda nyata pada BNT 5\% (BNT u = 0,02) pertambahan jumlah daun umur $16 \mathrm{MST}$, pada $(\mathrm{BNT} \mathrm{u}=0,01)$ pertambahan jumlah daun umur 20 MST, dan pada BNT 5\% (BNT u = 0,02) pertambahan jumlah daun umur 24 MST.

Berpengaruhnya pupuk Biourine Sapi terhadap pertambahan jumlah daun, hal ini diduga pada tanaman muda,.kadar $\mathrm{N}, \mathrm{P}$, dan $\mathrm{K}$ paling tinggi dijumpai pada pusat-pusat pertumbuhan, tidak terkecuali pada batang. Menurut Novizan, (2005), nitrogen adalah komponen utama dari berbagai substansi penting

\section{Interaksi Pupuk NPK Phonska dan Biourine Sapi}

\section{Pertambahan Tinggi Tanaman}

Tabel 7. Pengaruh Interaksi Pupuk NPK Phonska dan Biourine Sapi (PU) Terhadap Pertambahan RataRata Tinggi Tanaman $(\mathrm{cm})$

\begin{tabular}{cccc}
\hline Perlakuan Interaksi & \multicolumn{3}{c}{ Tinggi Tanaman } \\
\cline { 2 - 4 } $\begin{array}{c}\text { Pupuk NPK Phonska dan } \\
\text { Biourine Sapi }\end{array}$ & $16 \mathrm{MST}$ & $20 \mathrm{MST}$ & $24 \mathrm{MST}$ \\
\hline p0u0 & $7,33 \mathrm{f}$ & $11,00 \mathrm{f}$ & $10,33 \mathrm{~g}$ \\
p0u1 & $8,67 \mathrm{de}$ & $8,77 \mathrm{~g}$ & $19,33 \mathrm{f}$ \\
p0u2 & $14,33 \mathrm{bc}$ & $14,27 \mathrm{~d}$ & $20,00 \mathrm{f}$ \\
p1u0 & $8,67 \mathrm{ef}$ & $16,67 \mathrm{c}$ & $21,33 \mathrm{e}$ \\
p1u1 & $11,00 \mathrm{~cd}$ & $17,67 \mathrm{c}$ & $35,33 \mathrm{a}$ \\
p1u2 & $18,67 \mathrm{a}$ & $22,37 \mathrm{c}$ & $22,33 \mathrm{~d}$ \\
p2u0 & $14,33 \mathrm{~b}$ & $12,67 \mathrm{e}$ & $24,67 \mathrm{c}$ \\
p2u1 & $13,67 \mathrm{~b}$ & $20,87 \mathrm{~b}$ & $24,33 \mathrm{c}$ \\
p2u2 & $19,67 \mathrm{a}$ & $30,20 \mathrm{a}$ & $25,33 \mathrm{~b}$ \\
\hline
\end{tabular}

Keterangan : Angka yang diikuti huruf yang sama menyatakan tidak berbeda nyata pada BNT 5\% (BNT pu $=0,75)$ pertambahan tinggi tanaman umur $16 \mathrm{MST}$, pada $(\mathrm{BNT}$ pu $=1,15)$ pertambahan tinggi tanaman umur 20 MST, dan pada BNT 5\% (BNT pu $=0,75)$ pertambahan tinggi tanaman umur 24 MST.

Hasil sidik ragam menunjukkan bahwa pemberian pupuk NPK Phonska dan Biourine Sapi berpengaruh sangat nyata terhadap pertambahan tinggi tanaman umur 16, 20 dan 24 MST. Nilai tertinggi pada umur 16 MST adalah perlakuan $\mathrm{p}_{2} \mathrm{u}_{2}$ yaitu $90,60 \mathrm{~cm}$ dan yang terendah adalah perlakuan $\mathrm{p}_{0} \mathrm{u}_{1}$ yaitu $26,32 \mathrm{~cm}$. didalam tanaman. Sekitar 40-50\% kandungan protoplasma yang merupakan substansi hidup dari sel tumbuhan terdiri dari senyawa nitrogen. Senyawa nitorgen digunakan oleh tanaman untuk membentuk asam amino yang akan diubah menjadi protein, terutama pada fase vegetatif seperti daun. 
Berpengaruhnya pemberian pupuk NPK Phonska dan Biourine Sapi terhadap pertambahan tinggi tanaman umur 16, 20 dan 24 MST, hal ini diduga nitrogen diperlukan dalam pembentukan sel-sel baru, protein, asam amino, enzim, hijau daun dan vitamin sangat terpenuhi. Jadi interaksi antara pupuk NPK Phonska dan Biourine Sapi dapat memenuhi unsur hara yang dibutuhkan oleh daun tanaman pisang rutai.Menurut Winarso, (2005), unsur hara yang diserap tanaman berasal dari 3 sumber yaitu

\section{Diameter Batang}

Hasil sidik ragam menunujukkan bahwa pemberian pupuk NPK Phonska dan pupuk Biourine sapi berpengaruh sangat nyata terhadap diameter batang umur 16, 20 dan 24 MST. bahan organik, seperti salah satunya Biourine Sapi, sumber yang kedua yaitu mineral alami, ini tersedia pada batuan mineral yang membentuk tanah yang berubah menjadi unsur hara tersedia bagi tanaman yang telah mengalami penghancuran oleh cuaca salah satunya pupuk phosfat, yang ketiga unsur hara yang terikat, biasanya tidak dapat digunakan tanaman untuk melepasnya lewat pengaturan $\mathrm{pH}$ tanah sehingga menjadi tersedia bagi tanaman.

Jumlah tertinggi pada umur 16 MST adalah perlakuan $\mathrm{p}_{2} \mathrm{u}_{2}$ yaitu $6,71 \mathrm{~cm}$ dan nilai terendah adalah perlakuan $\mathrm{p}_{0} \mathrm{u}_{0}$ yaitu $4,49 \mathrm{~cm}$.

Tabel 8. Pengaruh Interaksi Pupuk NPK Phonska dan Biourine Sapi (PU) Terhadap Pertambahan RataRata Diameter Batang $(\mathrm{cm})$

\begin{tabular}{cccc}
\hline Perlakuan Interaksi & \multicolumn{3}{c}{ Diameter Batang } \\
\cline { 2 - 4 } $\begin{array}{c}\text { Pupuk NPK Phonska dan } \\
\text { Biourine Sapi }\end{array}$ & $16 \mathrm{MST}$ & $20 \mathrm{MST}$ & $24 \mathrm{MST}$ \\
\hline p0u0 & $1,75 \mathrm{f}$ & $1,47 \mathrm{e}$ & $1,63 \mathrm{~h}$ \\
p0u1 & $2,05 \mathrm{ef}$ & $3,82 \mathrm{bc}$ & $2,79 \mathrm{~g}$ \\
p0u2 & $2,79 \mathrm{~d}$ & $1,62 \mathrm{e}$ & $2,90 \mathrm{f}$ \\
p1u0 & $2,41 \mathrm{e}$ & $3,53 \mathrm{~cd}$ & $4,61 \mathrm{~d}$ \\
p1u1 & $3,52 \mathrm{c}$ & $4,20 \mathrm{ab}$ & $4,88 \mathrm{c}$ \\
p1u2 & $3,12 \mathrm{~d}$ & $4,62 \mathrm{a}$ & $5,47 \mathrm{a}$ \\
p2u0 & $3,49 \mathrm{c}$ & $3,03 \mathrm{~d}$ & $3,00 \mathrm{f}$ \\
p2u1 & $3,97 \mathrm{~b}$ & $2,95 \mathrm{~d}$ & $3,88 \mathrm{e}$ \\
p2u2 & $4,59 \mathrm{a}$ & $3,80 \mathrm{bc}$ & $5,14 \mathrm{~b}$ \\
\hline
\end{tabular}

Keterangan : Angka yang diikuti huruf yang sama menyatakan tidak berbeda nyata pada BNT 5\% (BNT pu $=0,11)$ diameter batang tanaman umur 16 MST, pada (BNT pu $=0,14$ ) diameter batang tanaman umur 20 MST, dan pada BNT 5\% (BNT pu $=0,19)$ diameter batang tanaman umur 24 MST.

Jumlah tertinggi pada umur 20 MST adalah perlakuan $\mathrm{p}_{1} \mathrm{u}_{2}$ yaitu $6,73 \mathrm{~cm}$ dan nilai terendah adalah perlakuan $\mathrm{p}_{0} \mathrm{u}_{0}$ yaitu $4,15 \mathrm{~cm}$. Jumlah tertinggi pada umur 24 MST adalah perlakuan $\mathrm{p}_{1} \mathrm{u}_{2}$ yaitu $7,22 \mathrm{~cm}$ dan jumlah terendah adalah perlakuan $\mathrm{p}_{0} \mathrm{u}_{0}$ yaitu $4,35 \mathrm{~cm}$.

Berpengaruhnya pemberian interaksi pupuk NPK Phonska dan Biourine Sapi terhadap pertambahan diameter batang umur 16, 20 dan $24 \mathrm{MST}$, hal ini diduga interaksi perlakuan $\mathrm{p}_{1} \mathrm{u}_{2}$ $(50 \mathrm{~g} /$ tanaman/polybag $+15 \mathrm{ml} /$ liter

\section{Jumlah Daun}

Hasil sidik ragam menunjukkan bahwa pemberian pupuk NPK Phonska dan Biourine sapi berpengaruh sangat nyata terhadap jumlah daun umur 16, 20, dan 24 MST. Jumlah tertinggi pada umur $16 \mathrm{MST}$ adalah perlakuan $\mathrm{p}_{2} \mathrm{u}_{2}$ yaitu 5,03 helai daun sedangkan yang terendah adalah perlakuan $\mathrm{p}_{0} \mathrm{u}_{0}$ dan $\mathrm{p}_{1} \mathrm{u}_{1}$ yaitu 3,66 helai daun. Pada umur 20 MST jumlah tertinggi adalah air/polybag) adalah yang optimal (parameter 20 dan 24 MST tertinggi). Seperti dinyatakan oleh Novizan (2005), bahwa unsur hara seperti nitrogen dibutuhkan untuk membentuk senyawa penting seperti klorofil, asam nukleat, dan enzim. Karena dibutuhkan dalam jumlah relatif besar pada tahap pertumbuhan tanaman, khususnya pada tahap pertumbuhan vegetatif, seperti pembentukan tunas atau perkembangan batang dan daun. perlakuan $\mathrm{p}_{2} \mathrm{u}_{2}$ yaitu 5,32 helai daun dan yang terendah adalah perlakuan $\mathrm{p}_{0} \mathrm{u}_{0}$ dan perlakuan $\mathrm{p}_{1} \mathrm{u}_{2}$ yaitu 3,51 helai daun sedangkan pada umur 24 MST jumlah tertinggi adalah perlakuan $\mathrm{p}_{2} \mathrm{u}_{2}$ yaitu 5,61 helai daun dan yang terendah adalah perlakuan $\mathrm{p}_{0} \mathrm{u}_{0}, \mathrm{p}_{0} \mathrm{u}_{1}, \mathrm{p}_{0} \mathrm{u}_{2}, \mathrm{p}_{1} \mathrm{u}_{0}$, dan $\mathrm{p}_{2} \mathrm{u}_{1}$ yaitu 4,38 helai daun. 
Tabel 9. Pengaruh Interaksi Pupuk NPK Phonska dan Biourine Sapi (PU) Terhadap Pertambahan RataRata Jumlah Daun (helai)

\begin{tabular}{cccc}
\hline $\begin{array}{c}\text { Perlakuan Interaksi } \\
\text { Pupuk NPK Phonska dan } \\
\text { Biourine Sapi }\end{array}$ & $16 \mathrm{MST}$ & $20 \mathrm{MST}$ & $24 \mathrm{MST}$ \\
\cline { 2 - 4 } p0u0 & $1,00 \mathrm{e}$ & $1,00 \mathrm{e}$ & $1,67 \mathrm{c}$ \\
p0u1 & $1,67 \mathrm{c}$ & $1,67 \mathrm{c}$ & $1,67 \mathrm{c}$ \\
p0u2 & $1,33 \mathrm{~d}$ & $1,33 \mathrm{~d}$ & $1,67 \mathrm{c}$ \\
p1u0 & $1,33 \mathrm{~d}$ & $1,33 \mathrm{~d}$ & $1,67 \mathrm{c}$ \\
p1u1 & $1,00 \mathrm{e}$ & $1,33 \mathrm{~d}$ & $1,33 \mathrm{~d}$ \\
p1u2 & $2,00 \mathrm{~b}$ & $1,00 \mathrm{e}$ & $2,00 \mathrm{~b}$ \\
p2u0 & $1,67 \mathrm{c}$ & $1,33 \mathrm{~d}$ & $2,00 \mathrm{~b}$ \\
p2u1 & $1,67 \mathrm{c}$ & $2,33 \mathrm{~b}$ & $1,67 \mathrm{c}$ \\
p2u2 & $2,33 \mathrm{a}$ & $2,67 \mathrm{a}$ & $3,00 \mathrm{a}$ \\
\hline
\end{tabular}

Keterangan : Angka yang diikuti huruf yang sama menyatakan tidak berbeda nyata pada BNT 5\% (BNT pu $=0,06)$ diameter jumlah daun umur $16 \mathrm{MST}$, pada (BNT pu $=0,05)$ jumlah daun umur $20 \mathrm{MST}$, dan pada BNT 5\% $(\mathrm{BNT} \mathrm{pu}=0,06)$ jumlah daun umur $24 \mathrm{MST}$.

Berpengaruhnya pemberian pupuk NPK Phonska dan Biourine Sapi terhadap pertambahan jumlah daun umur 16,20 dan 24 MST, hal ini tidak terlepas dari peran penyerapan unsur hara untuk pertumbuhan tanaman. Salah satu proses terpenting yang terjadi di alam adalah fotosintesis. Dalam proses ini karbondioksida dan air didalam sel korofil bereaksi dengan bantuan radiasi sinar matahari untuk memproduksi gula. Proses penyerapan tidak akan berhasil jika unsur hara tidak tersedia dan salah satu dari kedua perlakuan diatas adalah pemberian pupuk NPK Phonska dan

\section{KESIMPULAN}

1. Pemberian pupuk NPK Phonska dengan dosis $100 \mathrm{~g} /$ tanaman/polybag $\quad\left(\mathrm{p}_{2}\right) \quad$ dapat meningkatkan pertumbuhan bibit pisang rutai dimana pada parameter pertambahan tinggi tanaman tertinggi adalah pada16 dan 20 MST yaitu $15,89 \mathrm{~cm}$ dan $21,25 \mathrm{~cm}$, kemudian pada parameter pertambahan diameter adalah pada 16 MST yaitu $5,50 \mathrm{~cm}$, dan untuk parameter pertambahan jumlah daun adalah pada16,20 dan 24 MST yaitu1,89 helai, 2,11 helai dan 2,22 helai.

2. Pemberian Pupuk Biourine Sapi dengan dosis $15 \mathrm{ml} / \mathrm{liter}$ air/polybag $\left(\mathrm{u}_{2}\right)$ dapat meningkatkan pertumbuhan bibit pisang rutai dimana pada parameter pertambahan tinggi tanaman tertinggi adalah pada16, dan20 MST yaitu16,67 $\mathrm{cm}$ dan $22,28 \mathrm{~cm}$,kemudian pada

\section{DAFTAR PUSTAKA}

Anonim. 2006. Buletin Penggunaan Pupuk Organik Cair NASA. Natural Nusantara, Yogyakarta.
Biourine Sapi. Fase pertumbuhan vegetatif seperti pembentukan daun, batang dan akar sangat memerlukan unsur hara yang tersedia ini. Seperti dinyatakan oleh Novizan (2005), bahwa NPK merupakan unsur hara makro primer atau unsur hara esensial, unsur hara ini sangat diperlukan tanaman dan fungsinya tidak dapat digantikan oleh unsur lain. Jika jumlahnya kurang mencukupi tidak dapat digantikan oleh unsur lain. Juika jumlahnya kurang mencukupi, terlalu lambat tersedia, atau tidak diimbangi oleh unsur-unsur lain akan menyebabkan pertumbuhan tanaman terganggu.

parameter pertambahan diameter adalah pada 16 MST yaitu $63,50 \mathrm{~cm}$, dan untuk parameter pertambahan jumlah daun adalah pada16, dan 24 MST yaitu1,89 helai dan 2,22 helai.

3. Perlakuan interaksi antara pupuk NPK Phonska dan Biourine Sapi antara 100 gram pupuk NPK Phonska dan Biourine Sapi 15 $\mathrm{ml} /$ liter air/tanaman $\quad\left(\mathrm{p}_{2} \mathrm{u}_{2}\right) \quad$ dapat meningkatkan pertumbuhan tanaman pisang rutai, dimana pada parameter pertambahan tinggi tanaman adalah pada 16, 20 MST yaitu19,67 cm dan 30,20 cm, kemudian pada parameter pertambahan diameter adalah pada 16 MST yaitu $4,59 \mathrm{~cm}$, serta pada parameter pertambahan jumlah daun adalah pada16, 20 dan 24 MST yaitu5,14 helai, 2,67 helaidan 3,00 helai. 
Diakses Pada Tanggal 17 Maret 2013.

Anonim. 2009. Budidaya Tanaman Buah Unggul Indonesia, Agromedia Pustaka, Jakarta.

2010. Tanaman Buah Langka Dilestarikan. Harian Pos Kota Kalimantan Timur.

2013. Pupuk NPK Phonska. Petrokimia Gresik. Semarang.

Bilad. MR. 2011. Biourine Atau Urine Sebagai Pupuk Organik Cair. Alternatif Yang Lebih Baik .http://www.Sasak.Org. Diakses Pada Tanggal 29 April 2013.

Cahyono. B. 1996. Pisang, Budidaya dan Analisis Usaha Tani. Kanisius, Yogyakarta.

Hanafiah. K. A, 2003. Rancangan Percobaan, Teori dan Aplikasi, Edisi Ketiga, Raja Grafindo Persada. Jakarta.

Hardjowigeno. S. 2007 Ilmu Tanah. Akademika Presindo Jakarta.

Heru. P. 1996. Memupuk Tanaman Buah. Penebar Swadaya, Jakarta.

Lingga. P. 2007. Petunjuk Penggunaan Pupuk. Penebar Swadaya. Jakarta.
Novizan. 2002. Petunjuk Pemupukan yang Efektif. Agromedia Pustaka, Jakarta.

Parnata. S. 2004. Pupuk Organik Cair Aplikasi dan Manfaatnya, PT. Agromedia Pustaka, Tanggerang.

Rukmana. R. 1999. Usaha Tani Pisang. Kanisius.Yogyakarta.

Rismunandar. 1990. Bertanaman Pisang CV. Sinar Baru Bandung.

Rizki. N. 2012. Pemanfaatan" Biourine Plus " BagiPertanian. http//Kaltim Litbang.Deptan.co.id. Diakses Pada Tanggal17 Maret 2013.

Soetedjo. M.M. 2002. Pupuk dan Cara Pemupukan. RinekaCipta. Jakarta.

Satuhu, Suyanti dan Supriyadi, A. 2008. Pisang, Budidaya, Pengolahan, Dan Prospek Pasar, Penebar Swadaya, Jakarta.

Suriatna. 1988. Pupuk dan Pemupukan. Meltron Putro, Jakarta.

Winarso, Sugeng. 2005. Kesuburan Tanah. PenerbitGava Media.Yogyakarta. 